\title{
Evidence for a circulating sodium transport inhibitor in essential hypertension
}

\author{
L POSTON, R B SEWELL, S P WILKINSON, P J RICHARDSON, R WILLIAMS, \\ E M CLARKSON, G A MACGREGOR, H E DE WARDENER
}

\begin{abstract}
The active sodium transport of white cells and red cells obtained from patients with essential hypertension was impaired. Incubating white cells from normotensive subjects in serum obtained from patients with essential hypertension caused an impairment in sodium transport in the white cells of normotensive subjects similar to that found in the white cells of hypertensive patients. The impairment in sodium transport was due to a fall in the ouabain-sensitive component of the total sodium efflux rate constant. These results show that the serum of patients with essential hypertension contains a substance which influences sodium transport and that it has ouabain-like activity. They also suggest that it is this substance which causes the impairment in sodium transport in the leucocytes of patients with essential hypertension.

These findings support the hypothesis that the rise in blood pressure in patients with essential hypertension is due to an increased concentration of a circulating sodium transport inhibitor which is continuously correcting a tendency for sodium retention by the kidney.
\end{abstract}

Liver and Cardiac Unit, King's College Hospital, London SE5 9RS

L POSTON, BSC, senior research assistant (now at St Thomas's Hospital Medical School, London)

R B SEWELL, MB, FRACP, research fellow (now at Mayo Medical School, Rochester, Minnesota, USA)

$S$ P WILKINSON, MD, MRCP, consultant physician (now at the Royal Infirmary, Gloucester)

P J RICHARDSON, MB, MRCP, senior lecturer in cardiology and honorary consultant physician

$R$ WILLIAMS, MD, FRCP, director of liver unit

Department of Medicine, Charing Cross Hospital Medical School, London W6 8RF

E M CLARKSON, PHD, top biochemist

G A MACGREGOR, MA, MRCP, senior lecturer

$H$ E DE WARDENER, MD, FRCP, professor of medicine

\section{Introduction}

In 1952 Tobian and Binion ${ }^{1}$ described an increase in the sodium content of renal arteries in patients with hypertension. Since then there has been increasing confirmatory evidence that the circulating red and white cells of patients with essential hypertension have an abnormality of sodium transport, usually associated with an increased intracellular sodium concentration. ${ }^{2-13}$ It has been suggested that this is an inherited abnormality. ${ }^{211}$ On the other hand, it has recently been proposed that it is due to a circulating sodium transport inhibitor. ${ }^{14}$ To test this proposal we took white and red cells from normotensive subjects and incubated these in the plasma of patients with essential hypertension. We report here the results.

\section{Patients and methods}

White cells-The investigation was carried out in two men and eight women with essential hypertension. They were aged 30 to 58 years, and three were non-Caucasian. None was taking treatment at the time of the study, though three had received diuretic treatment up to one week before. Supine diastolic pressures ranged from 100 to $130 \mathrm{~mm} \mathrm{Hg}$ with a mean of $111 \div$ SEM $3 \mathrm{~mm} \mathrm{Hg}$. Control subjects were 25 normotensive volunteers aged 24 to 44 years. Leucocytes were isolated from peripheral venous blood and intracellular sodium concentration estimated as described..$^{15}$ The leucocyte sodium efflux rate constant was determined by the method of Hilton and Patrick, ${ }^{16}$ with separate determination of the ouabain-sensitive and ouabaininsensitive components. All experiments were carried out at $37^{\circ} \mathrm{C}$. Leucocytes from normotensive subjects were preincubated in serum obtained from hypertensive patients for 90 minutes $^{17}$ to see whether serum from hypertensive patients affected sodium fluxes of normal leucocytes. As a control for these experiments leucocytes from normotensive subjects were preincubated in the serum of normotensive subjects. Results are expressed as means \pm SEM. Statistical analyses were by Student's $t$ tests.

Red cells-This investigation was carried out in 12 patients with essential hypertension aged 25 to 50 years. None had received treatment for blood pressure. Supine diastolic pressures ranged from 100 to $121 \mathrm{~mm} \mathrm{Hg}$ with a mean of $109+1.48$. There were two women and 10 men, seven of whom were non-Caucasian. The 19 normotensive subjects (nine women and $10 \mathrm{men}$ ) were volunteers aged 20 to 62 years, five of whom were non-Caucasian. The study was performed on heparinised blood. Measurements of intracellular sodium concen- 
tration and flux studies were performed after the red cells had been incubated at $37^{\circ} \mathrm{C}$ in the individual's own plasma at a concentration of approximately $1000 \times 10^{\circ} / 1$ for five hours. Intracellular sodium concentration was measured after centrifuging the cells at $15000 \mathrm{~g}$ in special tubes with a capacity of $0.04 \mathrm{ml}$. Trapped medium using ${ }^{51} \mathrm{Cr}$-EDTA was $1 \cdot 7^{\circ} \%$. Net sodium ${ }^{22} \mathrm{Na}$ influx and the rate constant for total ${ }^{22} \mathrm{Na}$ efflux were measured by the method of Glynn. ${ }^{18}$ Separate determination of ouabain-sensitive and ouabain-insensitive efflux was not performed. In cross-incubation experiments the red cells of normotensive subjects were incubated in their own plasma and in the plasma of hypertensive patients. The intracellular sodium concentration and the rate constant for total ${ }^{22} \mathrm{Na}$ efflux were measured in both groups of cells after five to 48 hours of incubation. These incubation experiments were performed between individuals whose red cells and plasma were compatible and under confirmed sterile conditions. Results are expressed as means \pm SEM. Statistical analyses were by the Mann-Whitney $U$ test for unpaired observations.

\section{Results}

White cells-The mean leucocyte sodium concentration measured in eight of the 10 hypertensive patients was $140 \pm 21 \mathrm{mmol}(\mathrm{mEq}) / \mathrm{kg}$ dry cell weight. This was significantly higher than that of the 25 normotensive subjects, in whom it was $72 \pm 3 \mathrm{mmol} / \mathrm{kg}$ dry cell weight $(p<0.01)$. The total sodium efflux rate constant of the leucocytes of the hypertensive patients $(2 \cdot 71 \pm 0 \cdot 14 / \mathrm{h})$ was significantly lower than that of the leucocytes from the normotensive subjects $(3 \cdot 79 \pm 0 \cdot 06 / \mathrm{h})$ $(p<0.001)$ due to a reduction in the ouabain-sensitive component of the rate constant (table). When leucocytes from a normotensive subject were preincubated in serum from another normotensive -might be extended to explain essential hypertension in man. They suggested that the primary abnormality in essential hypertension in man is in the kidney, as has been shown so clearly by cross-transplantation of kidneys in two genetic forms of hypertension in rats ${ }^{20-24}$; and that this difficulty in excreting sodium tends to cause an increase in extracellular volume which is continuously being corrected by an increased concentration of a circulating substance that, by inhibiting sodium reabsorption in the tubule, increases sodium excretion. As a result the extracellular fluid volume in essential hypertension is within normal limits ${ }^{25}$ but, as Blaustein ${ }^{26}$ pointed out, a rise in the concentration of a circulating sodium transport inhibitor on smooth muscle might increase the tone of the arterioles and cause a rise in blood pressure. According to de Wardener and MacGregor's hypothesis, the abnormality in sodium transport and increase in intracellular sodium concentration found in the white and red cells of patients with essential hypertension ${ }^{2-18}$ are due to a circulating sodium transport inhibitor and not to a hereditary defect of the cells themselves. ${ }^{\circ}$

The results of our leucocyte cross-incubation experiment support the hypothesis. The white cells obtained from the hypertensive patients had an increased intracellular sodium concentration and a reduction in the rate constant for total sodium efflux, as originally described by Edmondson et al. ${ }^{\mathrm{s}}$ When the white cells obtained from normotensive subjects were incubated in the plasma of hypertensive patients they developed an impairment of sodium transport which was similar to that found in the hypertensive patients' own white cells: there was a

Sodium efflux rate constant of leucocytes from normotensive subjects and hypertensive patients and of leucocytes from normotensive subjects after preincubation in plasma from normotensive subjects and hypertensive patients. Results are means $\pm S E M$

\begin{tabular}{|c|c|c|c|}
\hline & $\begin{array}{l}\text { Total sodium efflux } \\
\text { rate constant } \\
(/ \mathrm{h})\end{array}$ & $\begin{array}{c}\text { Ouabain-sensitive } \\
\text { sodium efflux rate } \\
\text { constant } \\
(/ \mathrm{h})\end{array}$ & $\begin{array}{c}\text { Ouabain-insensitive } \\
\text { sodium efflux rate } \\
\text { constant } \\
(/ \mathrm{h})\end{array}$ \\
\hline $\begin{array}{l}\text { Leucocytes of normotensive subjects }(n=19) \\
\text { Leucocytes of hypertensive patients }(n=9)\end{array}$ & $\begin{array}{l}3 \cdot 79+0 \cdot 06 \\
2 \cdot 71+0 \cdot 14^{* * *}\end{array}$ & $\begin{array}{l:l}2.79 & 0.07 \\
1.89 & 0.15^{* * *}\end{array}$ & $\begin{array}{l}1.01+0.03 \\
0.83+0.08\end{array}$ \\
\hline $\begin{array}{l}\text { Preincubation: normal leucocytes in normal serum }(n=11) \\
\text { Preincubation: normal leucocytes in hypertensive serum }(n=8)\end{array}$ & $\begin{array}{l}3 \cdot 69 \div 0 \cdot 17 \\
2 \cdot 86 \pm 0 \cdot 19^{*}\end{array}$ & $\begin{array}{l:l}2.55 & 0 \cdot 12 \\
1.81 & 0 \cdot 15^{* *}\end{array}$ & $\begin{array}{l}1 \cdot 15 \div 0 \cdot 11 \\
1.03 \div 0 \cdot 10\end{array}$ \\
\hline
\end{tabular}

subject the sodium efflux rate constant was similar to that of leucocytes which had not been preincubated in another person's serum. The preincubation of leucocytes from normotensive subjects in the serum of hypertensive patients caused a pronounced fall in the total sodium efflux rate constant-from $3 \cdot 69 \pm 0 \cdot 17 / \mathrm{h}$ to $2 \cdot 86+0 \cdot 19 / \mathrm{h}(\mathrm{p}<0 \cdot 01)$. This was due to a fall in the ouabain-sensitive component of the rate constant (table). The total and ouabain-sensitive component of the sodium efflux rate constant of the leucocytes obtained from normotensive subjects after incubation in the serum of hypertensive patients was not significantly different from the rate constant of the leucocytes of hypertensive patients.

Red cells-The mean sodium concentration in the red cells of the 12 hypertensive patients was $11 \cdot 0 \pm 0.8 \mathrm{mmol}(\mathrm{mEq}) / 1$ and in the red cells of the 19 normotensive subjects $8.4 \pm 0.5 \mathrm{mmol} / 1(\mathrm{p}<0.02)$. Net ${ }^{22} \mathrm{Na}$ influx of the red cells of hypertensive patients was $3.1+0.6 \mathrm{mmol} / \mathrm{l} / \mathrm{h}$ and of the cells of normotensive subjects $2.4 .0 .5 \mathrm{mmol} / \mathrm{h} / \mathrm{h}(\mathrm{p}<0.05)$. The rate constant for total ${ }^{22} \mathrm{Na}$ efflux of the cells of hypertensive patients was $0.35+0.04 / \mathrm{h}$ and in the cells of the normotensive subjects $0.46 \pm 0.02 / \mathrm{h}(\mathrm{p}<0.01)$. Though the total ${ }^{22} \mathrm{Na}$ efflux of the cells of the hypertensive patients was higher than that of the normotensive subjects-3.5 $0.23 \mathrm{mmol} / \mathrm{l} / \mathrm{h}$ compared with $3.2-0.18 \mathrm{mmol} / \mathrm{l} / \mathrm{h}$ the difference was not significant. Incubation of red cells from the normotensive subjects in the plasma of hypertensive patients did not impair their sodium transport.

\section{Discussion}

de Wardener and MacGregor ${ }^{14}$ proposed that Dahl's hypothesis $^{19}$-namely, that the rise in arterial pressure in the saitsensitive strain of hypertensive rats is due to a saluretic substance reduction in the total sodium efflux rate constant that was due to a reduction in the ouabain-sensitive component. These results show that the serum of patients with hypertension contains a substance which influences sodium transport and that it has ouabain-like activity.

The intracellular sodium concentration of the red cells from hypertensive patients was greater than in the red cells from normotensive subjects. This was mainly due to a pronounced reduction in the rate constant for total sodium efflux in the cells of the hypertensive patients. This confirms the findings of Aderounmu and Salako, ${ }^{13}$ who also showed that the reduction was due to a decrease in the ouabain-sensitive sodium efflux. Incubation of red cells obtained from normotensive subjects in plasma obtained from hypertensive patients failed to cause a change in their sodium transport. The different response of normal red cells when compared with that of white cells incubated in the plasma of hypertensive patients may be due to the difference in experimental conditions imposed by the different rates of sodium turnover in red and white cells. The concentration of red cells during incubation was approximately $1000 \times 10^{9} / 1$, while that of white cells was $2 \times 10^{9} / 1$. The greater concentration of red cells was technically convenient for the isotope-counting procedure and the measurement of intracellular sodium because of the slower rate of sodium turnover and lower sodium concentration of red cells. In order to produce a detectable effect the greater number of red cells may need a larger amount of sodium transport inhibitor than that contained in the small volume of plasma used in the cross-incubation experiment.

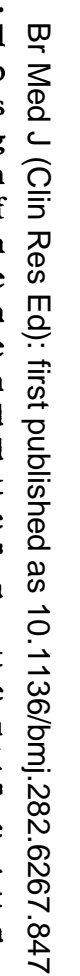




\section{References}

1 Tobian L Jr, Binion JT. Tissue cations and water in arterial hypertension. Circulation 1952;5:754-8.

${ }^{2}$ Losse $\mathrm{H}$, Wehmeyer $\mathrm{H}$, Wessels $\mathrm{F}$. The water and electrolyte content of erythrocytes in arterial hypertension. Klin Wochenschr 1960;38:393-5.

${ }^{3}$ Gessler Von U. Intra-und extrazelluläre elektrolytveränderungen bei essentieller hypertonie bor und nach behandlung. $Z$ Kreislaufforsch $1962 ; 51: 177-83$

${ }^{4}$ Wessels VF, Junoe-Hüsling G, Losse $H$. Unter suchungen zur natriumpermeabilität der erythrozyten bei hypertonikern und normotonikern mit familiärer hochdruckbelastung. $Z$ Kreislaufforsch 1967;56:374-80.

${ }^{5}$ Postnov YV, Orlov SN, Shevchenko A. Adler AM. Altered sodium permeability, calcium binding and Na-K-ATPase activity in the red blood cell membrane in essential hypertension. Pfluegers Arch 1977;371 : 263-9.

${ }^{6}$ Garay RP, Meyer P. A new test showing abnormal net $\mathrm{Na}^{+}$and $\mathrm{K}^{+}$fluxes in erythrocytes of essential hypertensive patients. Lancet 1979;i:349-53.

${ }^{7}$ Henningsen NC, Mattsson S, Nosslin B, Nelson D, Ohlsson O. Abnormal whole-body and cellular (erythrocytes) turnover of ${ }^{22} \mathrm{Na}^{+}$in normotensive relatives of probands with established essential hypertension. Clinical Science 1979;57:321-4s.

${ }^{8}$ Edmondson RPS, Thomas RD, Hilton PJ, Patrick J, Jones NF. Abnormal leucocyte composition and sodium transport in essential hypertension. Lancet 1975 ; : $1003-5$.

9 Thomas RD, Edmondson RPS, Hilton PJ, Jones NF. Abnormal sodium transport in leucocytes from patients with essential hypertension and the effect of treatment. Clinical Science and Molecular Medicine 1975; 48:169-70s.

10 Ambrosioni E, Tartagni F, Montebugnoli L, Magnani B. Intralymphocytic sodium in hypertensive patients: a significant correlation. Clinical Science 1979;57:325-7s.

11 Garay RP, De Mendonca M, Elghozi JL, et al. Clinical and pathological relevance of erythrocyte cation fluxes measurement in hypertension. Clinical Science 1979;57:329-31s.

12 Araoye MA, Khatri IM, Yao LLY, Freis ED. Intracellular sodium in hypertensive patients. Clinical Research 1978;26:53.

13 Aderounmu AF, Salako LA. Abnormal cation composition and transport in erythrocytes from hypertensive patients. Eur $\mathcal{F}$ Clin Invest 1979;9: 369-75.
14 de Wardener HE, MacGregor GA. Hypothesis: further observations on Dahl's hypothesis that a saluretic substance may be responsible for a sustained rise in arterial pressure. Its possible role in essential hypertension. Kidney Int 1980;18:1-9.

15 Jones R, Poston L, Hinestrosa H, Parsons V, Williams R. Weight gain between dialyses in diabetics: possible significance of raised intracellular sodium content. Br Med f 1980;280:153.

${ }^{16}$ Hilton PJ, Patrick J. Sodium and potassium flux rates in normal leucocytes in an artificial extracellular fluid. Clinical Science $1973 ; 44: 439-45$.

17 Alam AN, Poston L, Wilkinson SP, Golindano CG, Williams R. A study in vitro of the sodium pump in fulminant hepatic failure. Clinical Science and Molecular Medicine 1978;55:255-63.

${ }^{18}$ Glynn M. Sodium and potassium measurements in human red cells. $\mathcal{F}$ Physiol (Lond) 1956;134:278-310.

19 DahI LK, Knudsen KD, Iwai J. Humoral transmission of hypertension: evidence from parabiosis. Circ Res 1969;24.25, suppl 1:21-33.

20 Tobian L, Coffee K, McCrea P, Dahl LK. A comparison of the antihypertensive potency of kidneys from one strain of rats susceptible to salt hypertension and kidneys from another strain resistant to it. $\mathcal{F ~ C l i n}$ Invest $1966 ; 45: 1080$.

${ }^{21}$ Dahl LK, Heine M. Primary role of renal homografts in setting chronic blood pressure levels in rats. Circ Res 1975;36:692-6.

${ }^{22}$ Dahl LK, Heine M, Thompson K. Genetic influence of the kidneys on blood pressure. Evidence from chronic renal homografts in rats with opposite predispositions to hypertension. Circ Res 1974;34:94-101.

${ }^{23}$ Bianchi G, Fox U, Di Francesco GF, Giovanetti AM, Pagetti D. Blood pressure changes produced by kidney cross-transplantation between spontaneously hypertensive rats and normotensive rats. Clinical Science and Molecular Medicine 1974;47:435-48.

${ }^{24}$ Fox U, Bianchi G. The primary role of the kidney in causing the blood pressure difference between the Milan hypertensive strain (MHS) and normotensive rats. Clin Exp Pharmacol Physiol 1976;3, suppl:71-4.

${ }^{25}$ Birkenhager WH. Body-fluid volume in low-renin hypertension. Lancet $1974 ;$ ii:310-1.

26 Blaustein MP. Sodium ions, calcium ions, blood pressure regulation, and hypertension: a reassessment and a hypothesis. Am $\mathcal{F}$ Physiol 1977;232 (3):C165-73.

(Accepted 5 fanuary 1981)

\title{
Glucose turnover and metabolic and hormonal changes in ethanol-induced hypoglycaemia
}

\author{
N M WILSON, P M BROWN, S M JUUL, S A PRESTWICH， P H SÖNKSEN
}

\begin{abstract}
Infusion of $67 \mathrm{~g}$ ethanol over four hours in fasted, nonobese normal men (a) induced hypoglycaemia by inhibiting gluconeogenesis; (b) produced noticeable increases in blood lactate, 3-hydroxybutyrate, and free fatty acid concentrations; (c) depressed plasma growth hormone concentrations, despite hypoglycaemia; and (d) raised plasma cortisol concentrations before significant hypoglycaemia occurred. These metabolic changes were explained by the reduction of redox state which accompanies ethanol oxidation.

The pronounced changes in metabolic values recorded during this study suggested that the use of parenteral feeding regimens including ethanol needs to be reconsidered.
\end{abstract}

Department of Medicine, St Thomas's Hospital Medical School, London SE1 7EH

N M WILSON, BSC, medical student

$P$ M BROWN, $M B$, BS, lecturer in medicine

$S$ M JUUL, MSC, research fellow

S A PRESTWICH, HNC, medical laboratory scientific officer

P H SÖNKSEN, MD, FRCP, professor of endocrinology

\section{Introduction}

Ethanol-induced hypoglycaemia was first described by Brown and Harvey in 1941. ${ }^{1}$ The belief that chronic alcoholism was a prerequisite for the condition was refuted by several reports of its occurrence in children. Initially the hypoglycaemia was attributed to the hepatotoxicity of denatured alcohol solvents, and it was not until 1963 that ethanol alone was shown to be responsible." The pathophysiology of the condition is still not clear. The in-vitro studies of Freinkel $e t a l^{3}$ indicated that inhibition of glucose production was responsible, while Searle et $a l,{ }^{4}$ using metabolic tracer studies in vivo, implicated an increase in glucose utilisation.

In addition to its effect on glucose homoeostasis, ethanol metabolism reduces the cytosolic and mitochondrial redox states, $^{5}$ thus causing many changes in intermediary carbohydrate and fat metabolism. The effect of ethanol on the plasma free fatty acid concentration, however, is controversial: Freinkel et $a l^{2}$ reported a net rise, while Abramson and Arky ${ }^{6}$ observed a net fall. The response of ketone bodies is also not clear. Arky and Freinkel ${ }^{7}$ found a decline in blood acetoacetate concentration in response to ethanol oxidation, while Bagdade et $^{a^{8}}$ observed a rise. That insulin-induced hypoglycaemia leads to raised plasma growth hormone and cortisol concentrations is well known, but the hormonal response to acute alcohol ingestion is 